OPEN ACCESS

Edited by:

Kezhen Qi,

Shenyang Normal University, China

Reviewed by:

Saurabh Kulshrestha, Shoolini University of Biotechnology and Management Sciences, India

Zafar Hussain Ibupoto,

University of Sindh, Pakistan

${ }^{*}$ Correspondence:

Rosa Alduina

valeria.alduina@unipa.it

Maria Luisa Saladino

marialuisa.saladino@unipa.it

Specialty section:

This article was submitted to

Nanoscience,

a section of the journal

Frontiers in Chemistry

Received: 25 April 2020

Accepted: 07 July 2020

Published: 21 August 2020

Citation:

Presentato A, Armetta F, Spinella A, Chillura Martino $D F$, Alduina $R$ and Saladino ML (2020) Formulation of Mesoporous Silica Nanoparticles for Controlled Release of Antimicrobials for Stone Preventive Conservation.

Front. Chem. 8:699.

doi: 10.3389/fchem.2020.00699

\section{Formulation of Mesoporous Silica Nanoparticles for Controlled Release of Antimicrobials for Stone Preventive Conservation}

\author{
Alessandro Presentato ${ }^{1}$, Francesco Armetta ${ }^{1}$, Alberto Spinella ${ }^{2}$, \\ Delia Francesca Chillura Martino ${ }^{1,2}$, Rosa Alduina ${ }^{1 *}$ and Maria Luisa Saladino ${ }^{1 *}$ \\ 1 Department of Biological, Chemical, and Pharmaceutical Sciences and Technology (STEBICEF), University of Palermo, \\ Palermo, Italy, ${ }^{2}$ Advanced Technologies Network (ATeN) Center, University of Palermo, Palermo, Italy
}

The biotic deterioration of artifacts of archaeological and artistic interest mostly relies on the action of microorganisms capable of thriving under the most disparate environmental conditions. Thus, to attenuate biodeterioration phenomena, biocides can be used by the restorers to prevent or slow down the microbial growth. However, several factors such as biocide half-life, its wash-out because of environmental conditions, and its limited time of action make necessary its application repeatedly, leading to negative economic implications. Sound and successful treatments are represented by controlled release systems (CRSs) based on porous materials. Here, we report on the design and development of a CRS system based on mesoporous silica nanoparticles (MSNs), as a carrier, and loaded with a biocide. MSNs, with a diameter of $55 \mathrm{~nm}$ and cylindrical pores of ca. $3-8 \mathrm{~nm}$ arranged as parallel arrays concerning the NP diameter, and with $422 \mathrm{~m}^{2} / \mathrm{g}$ of specific surface area were synthesized by the sol-gel method assisted by oil in water emulsion. Biocide loading and release were carried out in water and monitored by UV-Vis Spectroscopy; in addition, microbiological assay was performed using as control the MCM-41 mesoporous silica loaded with the same biocide. The role of specific supramolecular interaction in regulating the release is discussed. Further, we demonstrated that this innovative formulation was useful in inhibiting the in vitro growth of Kocuria rhizophila, an environmental Gram-positive bacterial strain. Besides, the CRS here prepared reduced the bacterial biomass contaminating a real case study (i.e., stone derived from the Santa Margherita cave located in Sicily, Italy), after several months of treatment thus opening for innovative treatments of deteriorated stone artifacts.

Keywords: mesoporous silica nanoparticles, controlled release systems, condensation in emulsion, biocides, biodeterioration, stone conservation, cultural heritage

\section{INTRODUCTION}

Mesoporous silica nanoparticles (MSNs) are one of the most interesting recent findings in the field of materials chemistry (Farjadian et al., 2019). Thanks to the high percentage of hydroxyl groups in the inner walls of the pores and the high thermal and chemical stability and biocompatibility, MSNs have been used as nanoreactors for catalytic applications (Zhu et al., 2019) 
and as controlled release systems (CRSs) in the biological medicine (Slowing et al., 2008; Niu et al., 2014; Niculescu, 2020). Furthermore, MSNs have a high adsorption capacity guaranteed by the high value of pore volume and surface area, being their surface properties easily modifiable. Other interesting features of MSNs are their inert and biodegradable nature (Barbé et al., 2004; Lu et al., 2007; Trewyn et al., 2008; Lin and Haynes, 2009). As far as the drug delivery issue is concerned, MSNs are considered very promising because of their capacity in loading larger amounts of drugs as compared to conventional mesoporous materials (Du et al., 2013; Ma et al., 2013; Niu et al., 2014; Lu et al., 2015; Bernardos et al., 2019).

The development of alternative strategies based on either metal or metal-oxide nanoparticles (Russo et al., 2015, 2016; Qi et al., 2017, 2019, 2020; Cusimano et al., 2020; Yaqoob et al., 2020), as well as mesoporous ones (Cavallaro et al., 2018) and natural biocides (Fidanza and Caneva, 2019) has gained momentum mainly when it comes to the prevention of manufacture goods belonging to cultural heritage from chemicalor bio-deterioration phenomena (Artesani et al., 2020; David et al., 2020). Particularly, CRSs based on mesoporous materials have been developed to protect both environment and artifacts of archaeological and artistic interest (Popat et al., 2012; Ruggiero et al., 2019). Recent studies showed that the mesoporous silica can release biocides “on-demand" (Böttcher et al., 1999; Chan et al., 2017; Ruggiero et al., 2018). In this regard, the long-term actions of MSNs on paper (Michaelsen et al., 2013), woods (Liu et al., 2001), and stones (Allsopp et al., 2004; Eyssautier-Chuine et al., 2018) have been already assessed.

The development of CRSs of biocide for the preventive conservation of artifacts derives from the need to control the deteriogenic action of microorganisms on them. Indeed, bacteria and fungi contaminating artifacts can determine the rise of detrimental phenomena of the work of arts themselves, as microorganisms can release a vast array of metabolites (i.e., oxalic, citric, and sulphuric acids), extracellular enzymes, biological pigments, carotenoids, to name a few (Warscheid and Braams, 2000; Urzì, 2004). Thus, the interaction occurring between these biotic compounds and artifacts can lead to physicochemical and aesthetic alterations of the latter, demanding their treatment with expensive procedures. During a restoration work aimed to restrain the action of deteriogenic microorganisms, the restorers apply products whose efficacy would depend on the species to be contained, the artifacts' features, as well as physicochemical properties of the chosen product and its mode of application. Nowadays, most biocides feature high toxicity against both environment and operator, resulting in potentially noxious for human health especially in the case of museum environments. In this context, CRSs are of utmost interest as they could reduce the number of treatments over time concurrently guaranteeing the artifact protection.

With all this in mind, here, a new system consisting of mesoporous silica nanoparticles (MSNs) for the controlled release of biocides, long-term preventing and preserving both archaeological sites and museum environments from biodeterioration phenomena, is proposed. Specifically, the CRS was designed for the preventive conservation of stone material.
MSNs were prepared through the method of condensation in an emulsion and characterized by several physicochemical and biological analyses. Preventol RI-80 is a commercial biocide commonly used by restorers constituted by a mixture of quaternary ammonium salts, where the main component is benzyldimethyltridecylazanium chloride. In this study, it was chosen as a biocide, since it is active against a wide variety of fungi, algae, and bacteria contaminating stone materials, plasters, wood, and ceramics. Preventol RI-80 loading on and its release from MSNs were performed in water; further, the efficiency of the best CRS obtained was compared to that of mesoporous silica MCM-41 (Dresler et al., 2017). The validity of this formulation was supported by the application of the best CRS, in terms of the biocide release performance, on a real case study consisting of stone fragments deriving from a cave (named as Grotta di Santa Margherita) located in Castellammare del Golfo (Trapani, Italy). The ability of the system to locally kill microorganisms once applied on the stone materials was evaluated over 12 months, evaluating the microbial proliferation every 3 months, strengthening the suitable application of such material for the prevention of work of arts.

\section{MATERIALS AND METHODS}

\section{Materials}

Tetraethyl ortosilicate (TEOS, $d=0.934 \mathrm{~g} / \mathrm{mL} 99 \%$, Aldrich), cetyl-trymethyl ammonium bromide (CTAB 98\%, Aldrich), ethanol ( $d=0.789 \mathrm{~g} / \mathrm{mL} \geq 99.8 \%$, Fluka), $n$-heptane $(d=0.688$ $\mathrm{g} / \mathrm{mL} 99 \%$, Aldrich), ammonium hydroxide $(d=0.90 \mathrm{~g} / \mathrm{mL}, 30 \%$, Carlo Erba), and hydrochloric acid (37\%, Aldrich) were used without further purification. The synthesis of the MCM-41 was performed as reported elsewhere (Caponetti et al., 2010; Saladino et al., 2011; Lavall et al., 2012). MCM-41 had highly ordered hexagonal structures with toroidal particles of few microns. The specific surface area $S_{\mathrm{BET}}$ and the average pore size $\mathrm{w}_{\mathrm{BJH}}$ were 931 $\mathrm{m}^{2} / \mathrm{g}$ and $2.4 \mathrm{~nm}$, respectively. Preventol RI-80 was supplied by C.T.S. s.r.l. (Altavilla Vicentina (VI), Italy), being no information provided about the purity of the formulation. Aqueous solutions were prepared by weight, using conductivity grade water having $1.5 \mu \mathrm{S} / \mathrm{m}$ of conductivity.

\section{MSNs Synthesis}

MSNs were synthesized following the emulsion-condensation route reported by Cao et al. (2016), which involves the hydrolysis of alkoxysilanes followed by the reaction of polycondensation of the resulting silanol on a template consisting of CTAB surfactant molecules (Ma et al., 2011; Xu et al., 2014; Cao et al., 2016; Farjadian et al., 2019; Zhu et al., 2019). The oil phase (nheptane) determines the size of the nanopores by swelling the micelles and regulating the rate of hydrolysis of alkoxysilanes through the partitioning of the latter among the oil and aqueous phases. Besides, a stabilization of the emulsion either by the surfactant or the formed silica nanoparticles could occur. First, in a Nalgene bottle $70 \mathrm{~mL}$ of distilled water, $0.80 \mathrm{~mL}$ of ammonium hydroxide, $15 \mathrm{~mL}$ of $n$-heptane, $5 \mathrm{~mL}$ of ethanol and $0.5 \mathrm{~g}$ of $\mathrm{CTAB}$ were mixed at room temperature. Once the mixture became homogeneous, $2.6 \mathrm{~mL}$ of TEOS were added. The mixture 
was stirred at room temperature for $4 \mathrm{~h}$. To block the basecatalyzed reaction, $1.0 \mathrm{~mL}$ of hydrochloric acid was added to the formed suspension, which was then allowed to stand for $24 \mathrm{~h}$. The obtained product was thus filtered, washed with a mixture 1:1 of water and ethanol to remove $\mathrm{CTAB}$ and ammonium chloride formed as byproduct and dried at $60^{\circ} \mathrm{C}$ for about $72 \mathrm{~h}$, until the weight of the obtained white powder was constant.

\section{Characterization Techniques}

X-ray Diffraction (XRD) patterns were obtained using Philips PW 1050/39 diffractometer in Bragg-Brentano geometry (source $\mathrm{Cu} \mathrm{Ka}, \lambda=1.54056 \AA$, voltage $40 \mathrm{kV}$, current $30 \mathrm{~mA}$ ) in the range $2-60^{\circ}$, steps of $0.05^{\circ}$ and acquisition time 5 s/step.

The FT-IR spectra were acquired by using FT-IR Bruker Vertex $70 \mathrm{v}$ spectrophotometer with Platinum ATR, with $2 \mathrm{~cm}^{-1}$ steps and 60 scans in the acquisition range $4,000-400 \mathrm{~cm}^{-1}$. The measure was carried out at $2 \mathrm{hPa}$. A base line correction of the scattering was made.

NMR spectra were acquired by using a Bruker Advance II 400 spectrometer operating at the frequency of 400.15, 100.62, and $79.49 \mathrm{MHz}$ for the ${ }^{1} \mathrm{H},{ }^{13} \mathrm{C}$, and ${ }^{29} \mathrm{Si}$ nuclide, respectively. All samples were placed in $4 \mathrm{~mm}$ zirconia rotors equipped with Kelf caps. ${ }^{13} \mathrm{C}$ CPMAS NMR spectrum was acquired with a MAS rotation speed of $7 \mathrm{kHz}$, at a temperature of $300 \mathrm{~K}$ using a $90^{\circ}$ pulse on ${ }^{1} \mathrm{H}$ of $4.5 \mu \mathrm{s}$, a contact time during cross polarization of $2 \mathrm{~ms}$, a delay time of $3 \mathrm{~s}$ and 400 scans. ${ }^{29} \mathrm{Si}$ CPMAS NMR spectrum was acquired with a MAS rotation speed of $5 \mathrm{kHz}$, at a temperature of $300 \mathrm{~K}$ using a $90^{\circ}$ pulse on ${ }^{1} \mathrm{H}$ of $4.5 \mu \mathrm{s}$, a contact time during cross polarization of $8 \mathrm{~ms}$, a delay time of $5 \mathrm{~s}$ and 400 scans. Hartman-Hahn's conditions were optimized by standard samples of adamantane and of tetramethylsilane for ${ }^{13} \mathrm{C}$ and ${ }^{29}$ Si nuclei, respectively. The two compounds were also used as external chemical shift reference.

Transmission Electron Microscopy (TEM) investigation was performed by using a JEOL-2100 microscope operating at an accelerating voltage of $200 \mathrm{kV}$. The powders were dispersed in water and deposited on a copper grid. The observation of the samples was performed after complete evaporation of the solvent. The particle size distribution was determined by linear intercept method based on the TEM micrographs (Dai et al., 2018).

The $\mathrm{N}_{2}$ adsorption and desorption isotherms were recorded at $77 \mathrm{~K}$ using a Quantachrome Nova 2200 Multi-Station High Speed Gas Sorption Analyzer after degassing of the samples for $24 \mathrm{~h}$ at $23^{\circ} \mathrm{C}$ in the degas station. Adsorbed nitrogen volumes were normalized to the standard temperature and pressure. The specific surface area $\left(\mathrm{S}_{\mathrm{BET}}\right)$ was calculated according to the standard BET method in the relative absorption pressure $\left(\mathrm{P} / \mathrm{P}_{0}\right)$ range from 0.045 to 0.250 (Brunauer et al., 1938). The total pore volume $\left(\mathrm{V}_{\mathrm{t}}\right)$ was obtained from the nitrogen amount adsorbed in correspondence of $\mathrm{P} / \mathrm{P}_{0}$ equal to 0.99 . The cylinder diameter size ( $\mathrm{w}_{\mathrm{BJH}}$ ) was calculated by the BJH method (Kruk et al., 1999).

UV-vis spectra were recorded in the range 200-500 nm using a double beam Beckman DU-800 spectrophotometer with a resolution of $1.0 \mathrm{~nm}$. To avoid the effect of instrumental errors and of particle diffusion, the value of absorbance at $500 \mathrm{~nm}$ was subtracted to each spectrum. A typical spectrum of the Preventol RI-80 is reported in Figure S1.

\section{Biological Test}

The efficiency of the CRS was evaluated by means of disc diffusion antibiotic sensitivity assay, as reported elsewhere (Giardina et al., 2010; Ciabocco et al., 2018), using the Grampositive bacterial strain Kocuria rhizophila ATCC ${ }^{\circledR} 9341^{\mathrm{TM}}$ (K. rhizophila) since this species is frequently found on works of art and the stone materials (Warscheid, 2003; Randazzo et al., 2015). Briefly, a dense bacterial suspension $\left(\sim 10^{7}\right.$ cells) was prepared in the Luria Bertani growth medium (hereinafter named as LB and composed of $10 \mathrm{~g} / \mathrm{L}$ of sodium chloride, $5 \mathrm{~g} / \mathrm{L}$ of yeast extract, and $10 \mathrm{~g} / \mathrm{L}$ of tryptone) and spread onto LB-agar- $-20 \%$ $\mathrm{w} / \mathrm{v}$ of bacteriological agar-plates. Aqueous suspension aliquots containing different amounts of MSNs and biocides were directly spotted on sterile paper discs (6 $\mathrm{mm}$ diameter), which were deposited onto the bacterial overlay present in the LB-agar plate, as previously described (Rubino et al., 2018a). After overnight incubation at $30^{\circ} \mathrm{C}$, the diameter of the growth inhibition halos was registered. The antimicrobial activity was calculated as a mean of three replicates and standard deviations were calculated.

The release of biocides from the loaded MSN was followed over time (after $1,3,6,24$, and $48 \mathrm{~h}$ ) by collecting aliquots of the solution in which the CRS was immersed. The aliquots of solution were directly spotted on sterile paper discs and tested as aforementioned to detect antibacterial activity. Twenty microliters of Preventol RI-80 and the dispersions of the two mesoporous materials $\left(0.1_{\mathrm{w} / \mathrm{v}} \% \mathrm{MSN}\right.$ and $\left.0.1 \%{ }_{\mathrm{w} / \mathrm{v}} \mathrm{MCM}-41\right)$ were tested as controls.

To test the performance of the CRS based on MSNs loaded with Preventol RI-80, total viable bacterial count was measured, as previously described (Piacenza et al., 2018; Poma et al., 2019). Briefly, samples of $1 \mathrm{~g}$ of both untreated and treated stones were vigorously vortexed in $10 \mathrm{~mL}$ of $\mathrm{LB}$ to detach bacteria from the stone material. Serial dilutions of these suspensions were prepared using LB, being $100 \mu \mathrm{l}$ of each dilution spread onto LB-agar to allow bacterial growth. Plates were incubated at $30^{\circ} \mathrm{C}$ until colonies appeared. Data are reported as mean $(n=3)$ of the colony forming units (CFU) per $\mathrm{g}$ of stone and standard deviations were calculated.

After 1 year, the metagenomic DNA was extracted from these samples using the method reported in Presentato et al. (2020). PCR was carried out with primers and conditions used in Arizza et al. (2019).

\section{Loading Procedure and Experiments of Release}

The biocide loading was performed following the procedure reported elsewhere (Saladino et al., 2016; Dresler et al., 2017; Rubino et al., 2018b). One milligram/millilitre of the mesoporous powder was immersed in the aqueous solutions containing different biocide concentrations (range of the nominal concentration $0.012-0.64 \mathrm{v} / \mathrm{v} \%)$ for $24 \mathrm{~h}$ under continuous magnetic stirring in the dark. The values of concentration were chosen based on the restorer's suggestions. The suspension was centrifuged at appropriate RCF for the separation of the powder. Then, the supernatant was carefully removed and the loaded samples dried under vacuum 

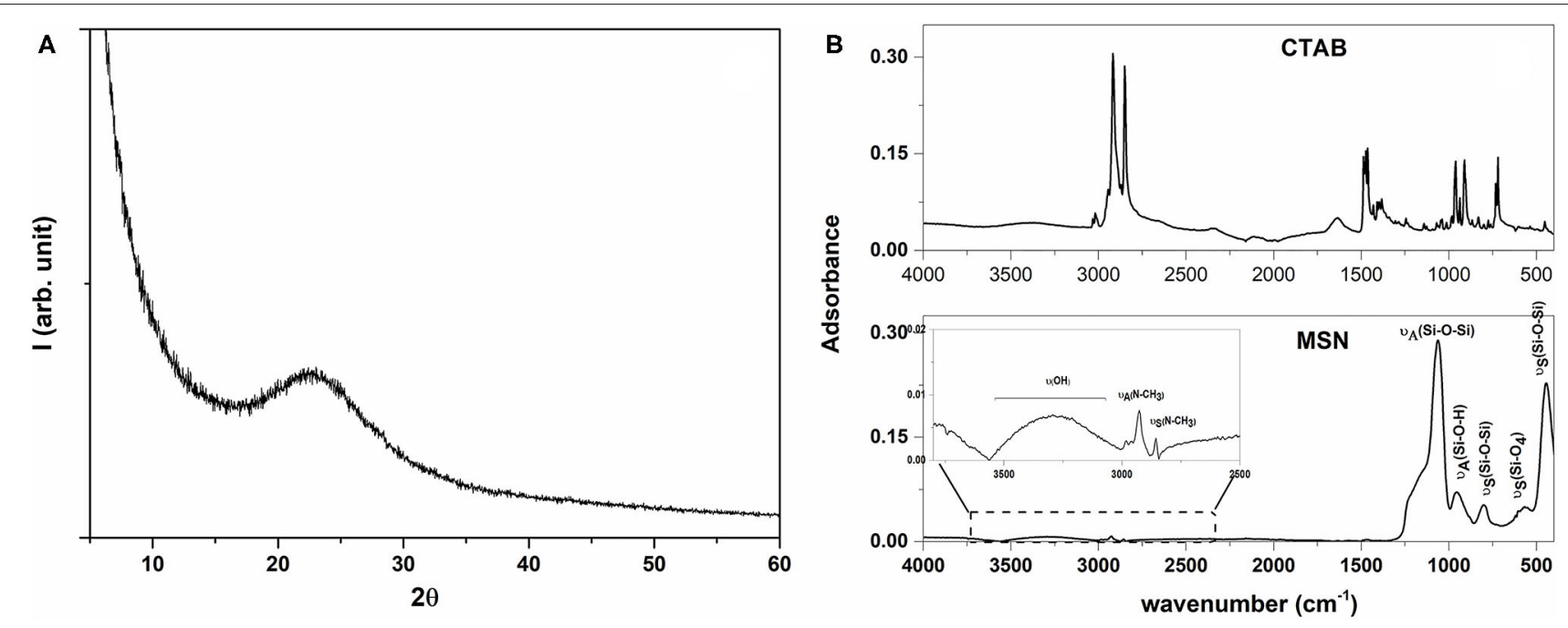

FIGURE 1 | XRD pattern (A) of synthesized MSN and FT-IR spectra (B) of CTAB and of synthesized MSN.

overnight. The loaded MSNs were white and similar to those unloaded. The yield of loading - which was evaluated by UVvis spectroscopy-was of $100 \%$ for all systems. The loaded MSN are called Preventol RI-80 $x @ \mathrm{NP} \mathrm{SiO}_{2}$ where $x$ is the initial concentration $(\mathrm{v} / \mathrm{v} \%)$ of the biocide in which MSNs were immersed. Preventol RI-80 loading within the MSNs was successful, as highlighted by the decreased MSN specific surface area $\left(41 \mathrm{~m}^{2} / \mathrm{g}\right)$ as compared to that of the unloaded material $\left(422.8 \mathrm{~m}^{2} / \mathrm{g}\right)$.

The following procedure was carried out to study the release of biocides from the MSN: $20 \mathrm{mg}$ of each biocide-loaded MSN were placed in a closed $3.5 \mathrm{kDa}$ dialysis membrane tube (Spectra/Por 3 Dialysis membrane) and then in a Nalgene-flask filled with $20 \mathrm{~mL}$ of water. The flask was kept at room temperature under continuous shaking during all the experiments. The UVvis spectra were registered on $2.5 \mathrm{~mL}$ of solution collected at the scheduled time $(1,3,6,24$, and $48 \mathrm{~h})$. The release profile was obtained plotting the values of concentration (obtained by Lambert Beer's law) vs. time and evaluating the antibacterial activity by disc diffusion antibiotic sensitivity assays, as described above. Each experiment was performed in triplicate.

\section{RESULTS AND DISCUSSION MSNs Characterization}

The physicochemical characterization of the synthesized MSNs was performed to ascertain the goodness of the material used as a carrier in this study. MSNs showed a broad band centered at $22^{\circ}$ in the XRD pattern (Figure 1A), which is ascribable to a silica amorphous material (Dubey et al., 2015; Jiang et al., 2019). The ATR spectrum (Figure 1B) of the sample did exhibit the trademark signs of silica (Mourhly et al., 2015). The most intense absorption bands, in the range between 1,000 and $1,300 \mathrm{~cm}^{-1}$ are due to the asymmetrical stretching of the $\mathrm{Si}-\mathrm{O}$-Si groups (i.e., 1,060 and $\left.1,232 \mathrm{~cm}^{-1}\right)$. The signal at $966 \mathrm{~cm}^{-1}$ is due to the SiO symmetric stretching, as well as the ones at 797 and $451 \mathrm{~cm}^{-1}$ (Mourhly et al., 2015). The broad band centered at $3,216 \mathrm{~cm}^{-1}$ (highlighted in the inlet of the Figure 1B) is due to the stretching of $\mathrm{O}-\mathrm{H}$ groups, which are indicative of the presence of hydrogen bonds resultant from the interaction occurring between the silanol groups $(\mathrm{Si}-\mathrm{OH})$ and the adsorbed water molecules. Accordingly, the signal observed in the ${ }^{29} \mathrm{Si}$ CP-MAS NMR spectrum (Figure 2) is due to the convolution of three peaks. The first peak (i.e., Q2; centered at ca. $90 \mathrm{ppm}$ ) was due to the geminal silanols, the second peak (i.e., Q3; centered at $100 \mathrm{ppm}$ ) highlighted silicon atoms bearing one hydroxyl group, while Q4 peak (centered at around $109 \mathrm{ppm}$ ) is due to each $\mathrm{Si}$ atom, which is linked over oxygen atoms with 4 Si neighbors (Saladino et al., 2008), which, overall, are contributions of mesoporous silica materials. Other than silica signals, IR spectra revealed vibration bands attributable to CTAB (Viana et al., 2012), as it is evident by comparing the spectrum of the MSN with that of $\mathrm{CTAB}$ (upper part of the Figure 1B). The signals falling between 1,250 and $1,500 \mathrm{~cm}^{-1}$ were due to the bending vibrational modes of $\mathrm{CH}_{2}$ groups, while those at 2,920 and $2,848 \mathrm{~cm}^{-1}$ were due to the asymmetric and symmetric stretching of the methyl and methylene groups. CTAB signals were also present in the ${ }^{13} \mathrm{C}$ CPMAS NMR spectrum (Figure 2). The resonance of the $\mathrm{N}-\mathrm{CH}_{2}$ and $\mathrm{N}-\mathrm{CH}_{3}$ groups was visible at 68 and $58 \mathrm{ppm}$ respectively, while the strong resonance at $30 \mathrm{ppm}$ derived from the methylene chain. Finally, the signals of the $\mathrm{CH}_{2}$ and $\mathrm{CH}_{3}$ end groups of the $\mathrm{CTAB}$ aliphatic chain were clearly visible at 27 and $23 \mathrm{ppm}$ (Xu et al., 2014). These findings evidenced that the CTAB was still present in the material, although several washing steps of MSNs were performed. Indeed, since the bands of ${ }^{13} \mathrm{C}$ nuclei were broad, it is reasonable to assert that the mobility of the molecule was low, likely indicating that the residual CTAB was located 

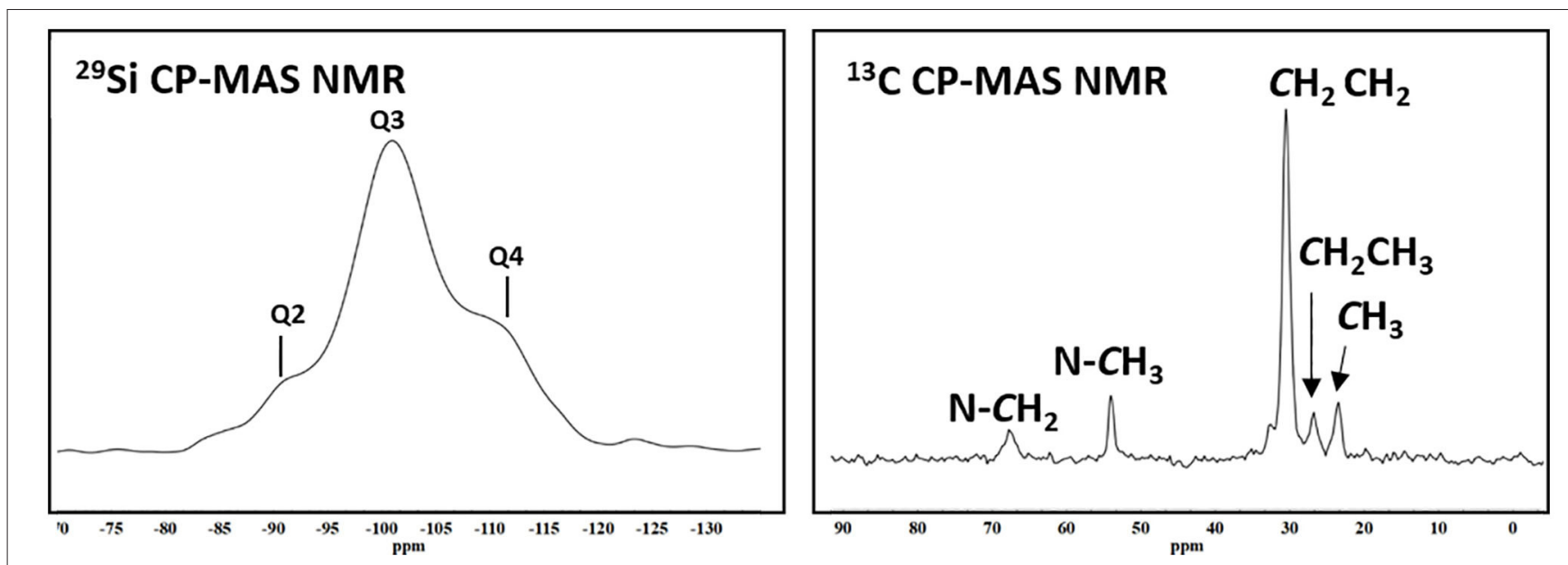

FIGURE $2 \mid{ }^{29} \mathrm{Si}$ CPMAS NMR and ${ }^{13} \mathrm{C}$ CPMAS NMR spectra of synthesized MSN
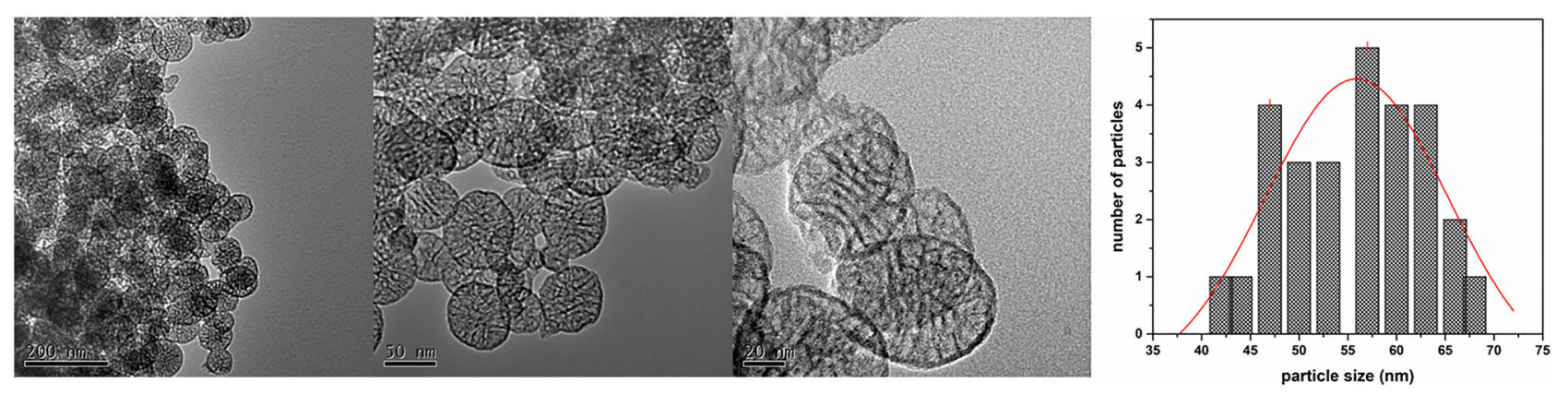

FIGURE 3 | TEM micrographs at different magnification of the obtained MSN and graph of particle size distribution.

within the pores of the mesoporous structure (Xu et al., 2014), therefore explaining the reason why it did not remove during the washing steps.

The isotherms of the sample were of Type IV-isotherm, and the hysteresis-type E of "ink-bottle" shape (Figure S2), according to IUPAC classification (Sing et al., 2008; Kraleva et al., 2011). The specific surface area, pore width, and the total pore volume of the synthesized MSN were $422 \pm 8$ $\mathrm{m}^{2} / \mathrm{g}, 3.7 \pm 0.1 \mathrm{~nm}$, and $0.90 \pm 0.02 \mathrm{~cm}^{3} / \mathrm{g}$, respectively. The observed high values of specific surface area are in line with those reported elsewhere (Nandiyanto et al., 2009), being also an indication of the mesoporous nature of the obtained silica, which can be used as a carrier because it should load high amount of biocide.

Some of the MSN's TEM micrographs at different magnification are reported in Figure 3 together with its size distribution, highlighting how the sample was composed of spherical nanoparticles of $55 \pm 10 \mathrm{~nm}$ (Figure 3), having also cylindrical pores of ca. three to eight nanometers, which were arranged as parallel arrays concerning the NP diameter. This morphology of MSNs is in good agreement with that of mesoporous nanoparticles investigated elsewhere (Slowing et al., 2008; Cao et al., 2016).

\section{Maintenance of the Antibacterial Activity of Preventol RI-80 After Loading}

Microbiological assays using decreasing percentages $(0.2-0.0002$ $\mathrm{v} / \mathrm{v} \%)$ of Preventol RI-80 demonstrated that $0.0002 \mathrm{v} / \mathrm{v} \%$ was sufficient to inhibit the growth of $K$. rhizophila (data not shown). Also, the maintenance of the antibacterial activity of the MSN system differently loaded with Preventol RI-80 was compared to that of MCM-41. Microbiological assays showed a large inhibition halo around Preventol RI-80 0.2@MSN than Preventol RI-80 0.1@MSN. Differently, 0.2\% of Preventol RI-80 loaded on MCM-41 barely inhibited the bacterial growth, while MCM-41 carrying $0.1 \%$ Preventol RI- 80 did not exert any antibacterial effect (Figure 4A). This finding demonstrated that the Preventol RI-80 loaded on MSN was more effective than the MCM-41based system in maintaining the activity against $K$. rhizophila. When we tested the antibacterial activity of $0.2 \mathrm{v} / \mathrm{v} \%$ Preventol RI80 and either unloaded $0.1 \% \mathrm{MCM}-41$ or $0.1 \% \mathrm{MSN}$ as controls, we found that MCM-41 was completely inactive, while MSN produced a small halo, probably due to the $\mathrm{CTAB}$ presence inside the pore structure (Figure 4B). Thus, we surmise that Preventol RI-80@MSN works better than Preventol RI-80@MCM-41 since the antibacterial activity derives from both Preventol RI- 80 and, even if at little extent, CTAB. 

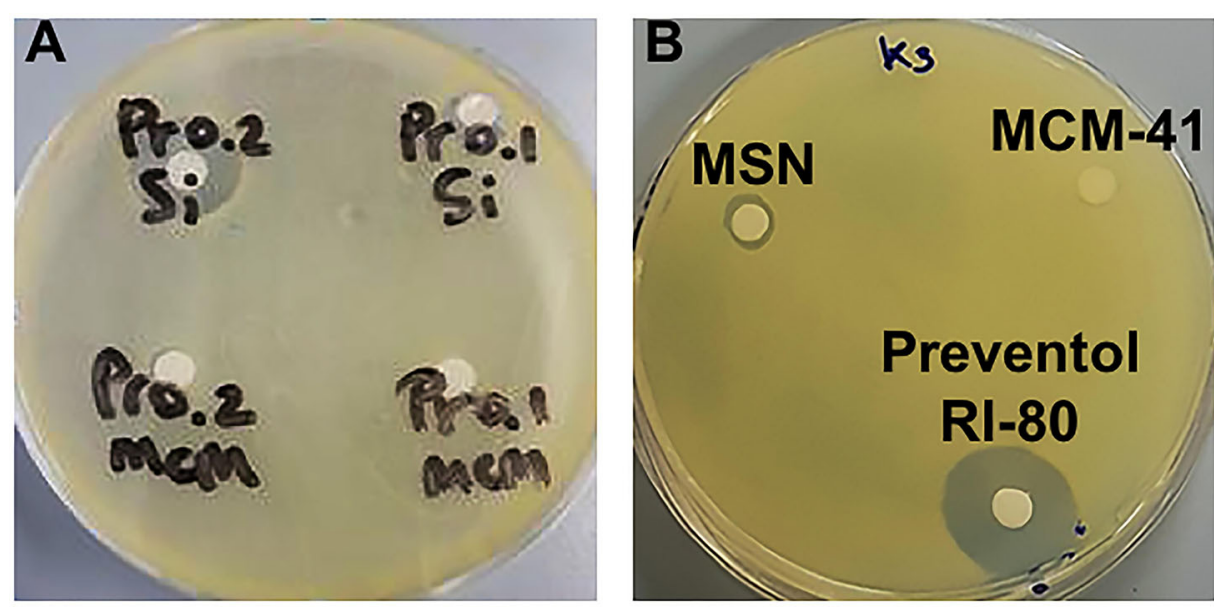

FIGURE 4 | Microbiological assays using K. rhizophila as a tester strain. Antibacterial activity (A) of Preventol RI-80 0.2@MCM-41 (Pr0.2MCM), Preventol RI-80 $0.1 @ \mathrm{MCM}-41$ (Pr0.1MCM), Preventol RI-80 0.2@MSN (Pro.2Si), and Preventol RI-80 0.1@MSN (Pro.1Si), while in (B) is highlighted the effect of either unloaded MSN or MCM-41 systems, as well as Preventol RI-80.

\section{Release Studies}

To evaluate biocide's release, MSNs loaded with various amounts of Preventol RI-80 were placed in the water and aliquots of the solution were collected at different sampling times. The release kinetics of Preventol RI-80 (Figure 5, Figure S3A) into the water solution was followed by recording intensities at two diverse wavelengths (210 and $260 \mathrm{~nm})$ to determine differences, if any, in the release of the different compounds present within the commercial formulation. Indeed, benzyldimethyltridecylazanium chloride, the main active compound of the quaternary ammonium salts mixture, has the maximum absorbance centered at ca. $260 \mathrm{~nm}$. Preventol RI-80 release was evaluated at the two wavelengths and, although the observed trends were similar, the equilibrium state was reached after either 1 or $3 \mathrm{~h}$ for benzyldimethyltridecylazanium chloride or the other components, which have the maximum absorbance at $210 \mathrm{~nm}$, respectively. Accordingly to the literature (Wang, 2009; Bruschi, 2015), the model of Higuchi was applied to the outcomes. The two-step regimes were observed suggesting that the load and then the release is controlled by both chemical and physical entrapping of the active compounds within the pores. The Higuchi constant was in the order Preventol RI-80@MSN $(260 \mathrm{~nm}), K_{H}=0.37 \pm 0.01 \mathrm{~s}^{-0.5}>$ Preventol RI-80@MSN $(210 \mathrm{~nm}), K_{H}=0.25 \pm 0.01 \mathrm{~s}^{-0.5}$, while differences in terms of the amount of biocide release were not observed. Similar results were observed in our previous studies regarding the loading of Biotin-T (constituted by the quaternary ammonium salt didecyldimethylammonium chloride and 2-octyl-2H-isothiazole) (Dresler et al., 2017). This behavior can be explained by a different physicochemical interaction between the hydroxyl groups of the silica and the biocide components and, accordingly to previous study (Dresler et al., 2017), could be ascribed to ion (charged head groups of quaternary salts)-dipole ( $\mathrm{Si}-\mathrm{O}-\mathrm{H}$ surface groups) interactions strengthened by the Lewis acid-base interaction among the phenyl group of benzyldimethyltridecylazanium

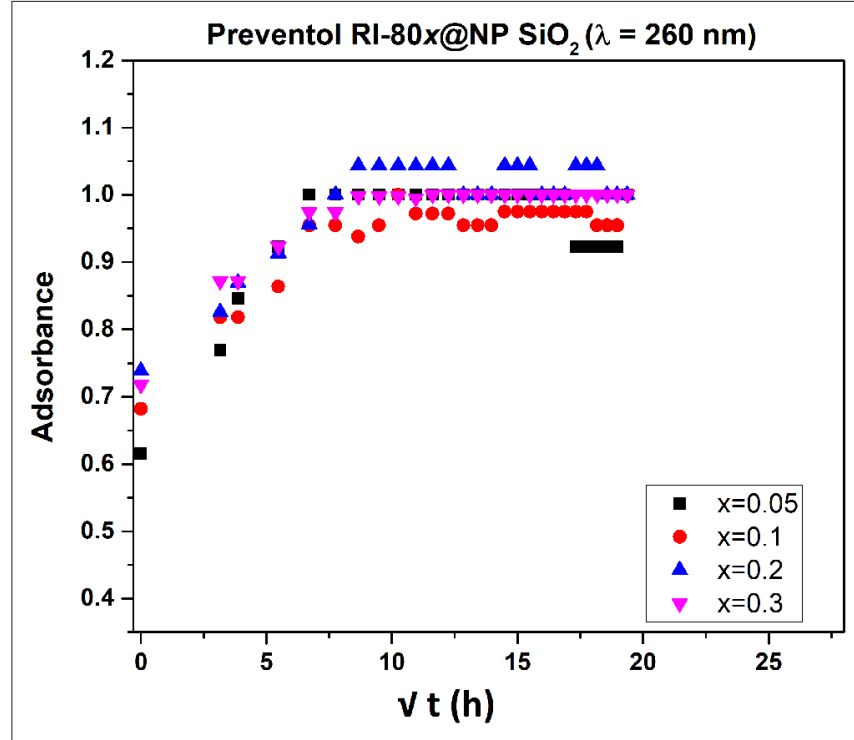

FIGURE 5 | Release profile of Preventol RI-80 from MSN loaded with different amounts of Preventol RI-80 ( $\lambda=260 \mathrm{~nm})$.

chloride and the acidic sites (electropositive $\mathrm{Si}$ ) in the MSN structure (Chauhan et al., 2020).

The release efficiency of Preventol RI-80-loaded within MSN was compared with Preventol RI-80 loaded within MCM41. It is worth mentioning that also MCM41 was efficiently loaded (100\%) with Preventol RI-80 as confirmed by the decrease of the specific surface area up to $50 \mathrm{~m}^{2} / \mathrm{g}$. The release kinetics of Preventol RI-80@MCM-41 followed the Higuchi model (Figures S3B,C); however, the Higuchi constant was in the opposite order as compared to MSNs (i.e., Preventol RI80@MCM-41 $(210 \mathrm{~nm}), K_{H}=0.43 \pm 0.02 \mathrm{~s}^{-0.5}>$ Preventol RI$80 @ M C M-41(260 \mathrm{~nm}), K_{H}=0.26 \pm 0.03 \mathrm{~s}^{-0.5}$ and, regardless 

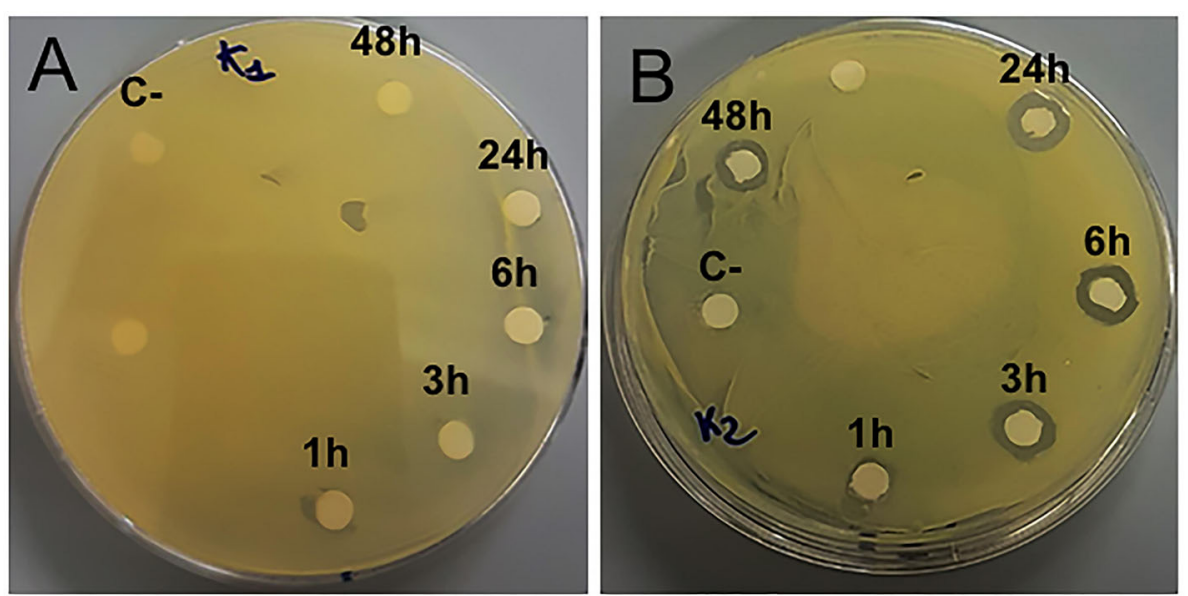

\section{Dreventol RI-80 0.3@MCM-41 \\ 口Preventol RI-80 0.3@MSN}

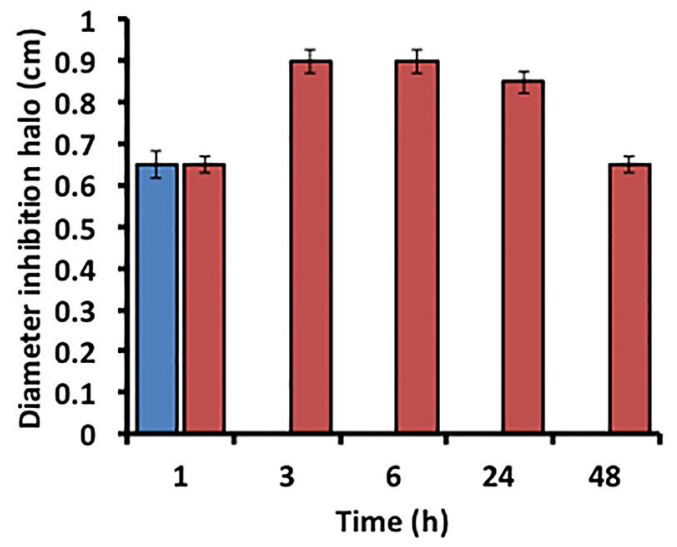

FIGURE 6 | Microbiological assays using K. rhizophila as tester strain. Antimicrobial activity of both Preventol RI-80 0.3@MCM-41 (A) and Preventol RI-80 0.3@MSN (B) CRSs, while the bar graph in (C) shows the actual diameter size of the inhibition halos, over time, ascribed to Preventol RI-80 0.3@MCM-41 (blue) and Preventol RI-80 0.3@MSN (red) systems activity.

the wavelength, the state of equilibrium was reached roughly after $1 \mathrm{~h}$.

These outcomes suggest a higher efficiency in releasing benzyldimethyltridecylazanium chloride by the Preventol RI80@MSN as compared with Preventol RI-80@MCM-41 probably due to a higher amount of acidic sites on the surface of MSN thus suggesting that the role of Lewis acid-base interaction is pivotal in regulating the release of biocides. On this basis, the MSN system was judged to be more suitable, in terms of release kinetics, for its application in a real case study; therefore, the biological activity of the Preventol RI-80 0.3@MSN system was compared to that of Preventol RI-80 0.3@MCM-41.

The biocide release was also studied by microbiological assays for the Preventol RI-80 0.3@MSN system over time (i.e., 1, 3, 6, 24, 48 h), being Preventol RI-80 0.3@MCM-41 one used as a comparison. The system Preventol RI-80 0.3@MSN maintained the antibacterial activity for a longer time than that based on MCM-41; indeed, the latter lost its activity after $1 \mathrm{~h}$ of application (Figure 6A), while the system Preventol RI-80 0.3@MSN resulted to be active up to $48 \mathrm{~h}$ (Figure 6B). Thus, the MSN-based system resulted to be more suitable as a carrier to achieve both biocide loading and release over time as compared to MCM-41 one, as also indicated by the inhibition halo values (Figure 6C). The difference could be due to CTAB traces in the system, as well as the different size and organization of the mesoporous pore structure. The release of $0.3 \%$ Preventol RI80 was completed within $1 \mathrm{~h}$ when MCM- 41 was used, while we had previously obtained the complete release of $0.75 \%$ Biotin$\mathrm{T}$ from MCM-41 within 6h (Dresler et al., 2017). Besides the diverse concentrations of biocides used, the difference could be ascribed to the different mechanism of interactions of benzyldimethyltridecylazanium chloride (Preventol RI-80) or 2-octyl-2H-isothiazole (Biotin T) and silica, even it could be influenced by the relative composition of the product (unknown). Therefore, Preventol RI-80 loaded within MSN was the most efficient CRS we designed so far. The release efficiency was in line to that observed for similar silica based CRS developed for the preventive conservation of artifacts (Sorensen et al., 2010; 


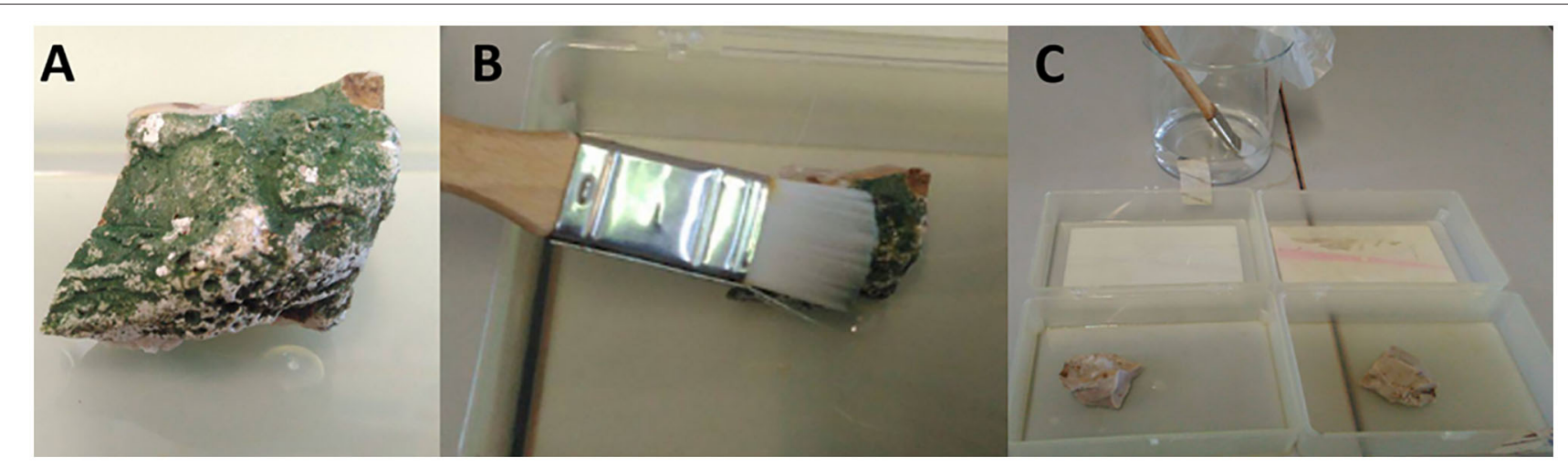

FIGURE 7 | Sample from the Santa Margherita's cave (A), treatment with Preventol RI-80 at 10v/v\%. (B), and application of the CRS (C)

TABLE 1 | Evaluation of the alive microbial biomass retrieved from either untreated or differently treated stone material.

\begin{tabular}{|c|c|c|c|c|}
\hline & \multicolumn{4}{|c|}{ Days of treatment } \\
\hline & 2 (days) & 10 (days) & 6 (months) & 12 (months) \\
\hline Sample & \multicolumn{4}{|c|}{ Colony forming units per gram of stone (CFU/g) } \\
\hline Untreated stone & $5 \pm 2$ & $13 \pm 3$ & $10 \pm 4$ & $15 \pm 2$ \\
\hline $\begin{array}{l}\text { Preventol RI-80 } \\
\text { treated stone }\end{array}$ & 0 & 0 & $1 \pm 1$ & $3 \pm 2$ \\
\hline $\begin{array}{l}\text { Preventol Rl- } \\
\text { 80@MSN-treated } \\
\text { stone }\end{array}$ & 0 & 0 & 0 & 0 \\
\hline
\end{tabular}

Borisova et al., 2011). On the other hand, it is well-known that the release could be triggered by external stimuli by proper functionalization of silica surface or that the use of layered double hydroxides ( $\mathrm{LDH})$ could give a dual role also acting in the capture of specific ions (Giuliani et al., 2020). It has to keep in mind that for applicative purposes, the balance among costs and benefits have to be accounted and, in some cases, low cost materials as natural clays (Cavallaro et al., 2018) could be advantageous.

\section{Test on Real Case Study: The Stone of the Castellammare Del Golfo's Cave}

The Santa Margherita's cave in Castellammare del Golfo (Trapani, Italy) is a natural cave, containing the remains of paintings belonging to an ancient church dated back to the middle age (Purpura, 1999) ${ }^{1}$. The cave is in a poor state of conservation and most of the paintings and the stone are contaminated by biodeteriogens. The identification of biodeteriogenic bacterial strains has been performed (data not shown), as well as the monitoring of environmental conditions (i.e., temperature and humidity), which demonstrated that in a full year there are the proper conditions allowing microbial

\footnotetext{
${ }^{1}$ Trapani oggi (2019). Gli affreschi della grotta di Santa Margherita. https://www. trapanioggi.it/gli-affreschi-della-grotta-di-santa-margherita (accessed April 25, 2020).
}

growth. Thus, fragments of the stone support represent a good case study to test the performances of the MSN system developed to treat damaged stone materials.

The Preventol RI-80 0.3@MSN system was applied to a sample taken from the west wall of the cave. The surface of the sample was covered by a green biopatina (Figure 7A), likely representing a microbial biofilm, as microorganisms growing in a sessile life form are more prone in handling harsh environmental conditions and stressors of various nature (i.e., antimicrobials) deriving from the surrounding ecological niche (Piacenza et al., 2017). To simulate a real treatment during the restoration works, the sample was treated with a solution of Preventol RI-80 (10 $\mathrm{v} / \mathrm{v} \%$ ) for $15 \mathrm{~h}$, being then washed with a water brush (Figure 7B). The green color disappeared after this application. The sample was then divided into two smaller fragments and one of them was used for applying the MSN-based CRS by using a brush (Figure 7C).

The presence of bacteria was evaluated by counting the viable cells and by extracting metagenomics DNA from the untreated stone, the sample treated with Preventol RI-80, and that treated with Preventol RI-80 and Preventol RI-80 0.3@MSN. Evaluation of viable bacteria showed that after 12 months no bacteria were present in samples treated with Preventol RI-80 and additionally with Preventol RI-80 0.3@MSN; differently, from the untreated stone, a mean of $15 \pm 2 \mathrm{CFU} / \mathrm{g}$ was found at the end of the timeframe considered, while Preventol RI-80 treated samples highlighted the presence of lower microbial contamination after 12 months (Table $\mathbf{1}$ ).

We cannot rule out that the initial treatment was so strong to completely inhibit bacterial growth for such a long time or that the conditions in which stones were stored did not allow further bacterial proliferation. Since a minority of environmental microorganisms (ca. 10\%) can be isolated through conventional cultivable-dependent methods (Soffritti et al., 2019), to further confirm the absence of bacteria on Preventol RI-80 0.3@MSNtreated stone, metagenomic DNA was extracted from the latter, which was used as a template to amplify a 464-base pair DNA internal fragment of the gene coding for the $16 \mathrm{~S}$ bacterial ribosomal subunit (Arizza et al., 2019). Agarose gel electrophoresis showed the amplicon of the correct size $(\sim 500$ 


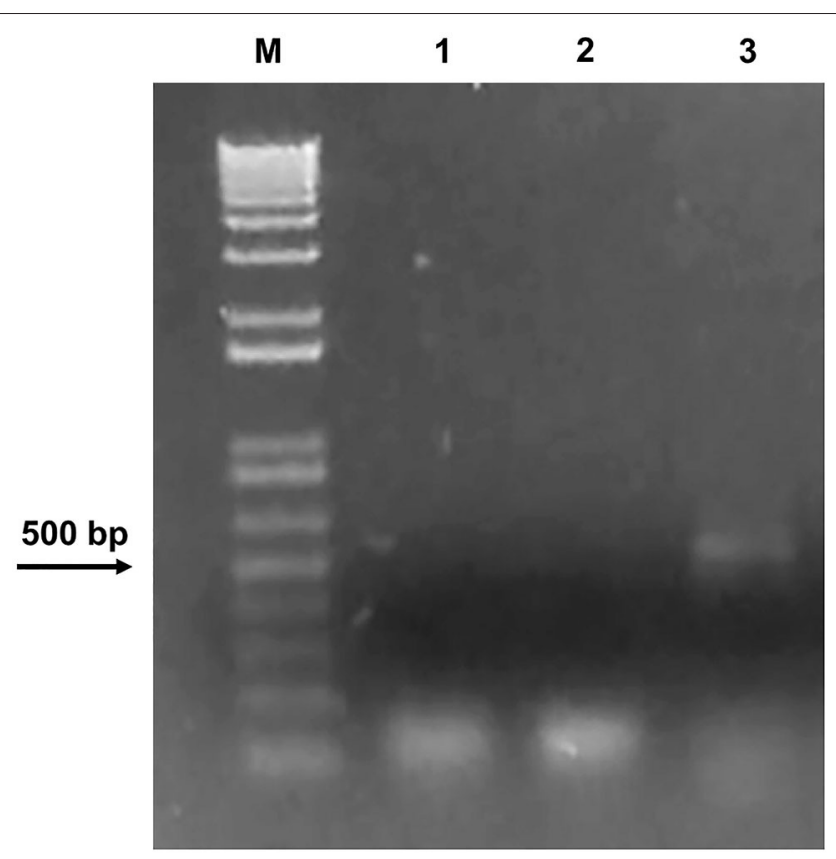

FIGURE 8 | Agarose gel electrophoresis showing DNA only in the untreated stone. M: DNA marker (1 Kb Plus DNA Ladder Biolabs ${ }^{\circledR}$ ). PCR was carried out using 1: water as a negative control; 2: DNA extracted from the Preventol RI-80 0.3@MSN-treated stone; 3: DNA extracted from the untreated stone.

bp) only in the untreated stone (Figure 8), thus confirming the efficacy of the treatment.

\section{CONCLUSIONS}

This study highlights new avenues in developing controlled release systems directed to a specific target (i.e., stone material) to reduce the frequency of antibacterial treatments of cultural heritage. The mesoporous silica nanoparticles were synthesized by condensation in emulsion method.

The MSNs, spherical in shape featuring having average diameter of $55 \mathrm{~nm}$, show cylinder pores of 3-8 $\mathrm{nm}$ in diameter. CRSs based on mesoporous silica nanoparticles with a high yield in loading the biocides Preventol RI-80 were developed and tested as a smart tool against the biodeterioration phenomenon of the material of archaeological and artistic interest.

Preventol RI-80 loaded on MSN showed a high approximation to a more efficient drug delivery system, even higher with respect to the MCM-41.

The antibacterial test showed that all systems are efficient against microbial blooming with MSN more active than MCM-41.

\section{REFERENCES}

Allsopp, D., Seal, K., and Gaylarde, C. (2004). Introduction to Biodeterioration. Cambridge: Cambridge University Press. 233. doi: $10.1017 / \mathrm{CBO} 9780511617065$
Finally, Preventol RI-80 0.3@MSN system was applied on a stone sample from the Santa Margherita cave in Castellammare del Golfo (Trapani, Italy). The bacterial growth was inhibited for 12 months after treatment. This work demonstrates that it is possible to use the CRSs against the deterioration and that, knowing the kind of biodeteriogens, it is possible to develop ad hoc systems to prevent the degradation of artifacts based on stone material. The use of the systems could be extended to other kinds of artifacts based on paper, woods, or metals.

\section{DATA AVAILABILITY STATEMENT}

The raw data supporting the conclusions of this article will be made available by the authors, without undue reservation.

\section{AUTHOR CONTRIBUTIONS}

RA and MS: Conceptualization and methodology. FA: preparation of samples. RA and AP: biological test. MS: XRD and FT-IR data. AS: NMR data. RA, DC, MS, and AP: writing-review and editing. All authors contributed to the article and approved the submitted version.

\section{FUNDING}

This work is part of the project Development and Application of Innovative Materials and processes for the diagnosis and restoration of Cultural Heritage-DELIAS-PON03PE 00214-2 (Programma Operativo Nazionale Ricerca e Competitività 20172013). Grants of AP and FA were from the MIUR for the Project PON Ricerca e Innovazione 2014-2020-Avviso DD 407/2018 AIM Attrazione e Mobilità Internazionale (AIM1808223).

\section{ACKNOWLEDGMENTS}

We thank Leonardo Borgioli of C.T.S. s.r.l. for providing the biocides. We would like to express our gratitude to Soprintendenza di Trapani (Italy) and Prof. Sebastiano Tusa for the permission to perform the experiments on the samples collected at Santa Margherita Cave. NMR and TEM experimental data were provided by ATeN Center-University of Palermo (https://www.unipa.it/servizi/atencenter/).

\section{SUPPLEMENTARY MATERIAL}

The Supplementary Material for this article can be found online at: https://www.frontiersin.org/articles/10.3389/fchem. 2020.00699/full\#supplementary-material

Arizza, V., Vecchioni, L., Caracappa, S., Sciurba, G., Berlinghieri, F., Gentile, A., et al. (2019). New insights into the gut microbiome in loggerhead sea turtles Caretta caretta stranded on the Mediterranean coast. PLoS ONE 14:e0220329. doi: 10.1371/journal.pone.02 20329 
Artesani, A., Di Turo, F., Zucchelli, M., and Traviglia, A. (2020). Recent advances in protective coatings for cultural heritage-an overview. Coatings 10:217. doi: 10.3390/coatings10030217

Barbé, C., Bartlett, J., Kong, L., Finnie, K., Linn, H. Q., Larkin, M., et al. (2004). Silica particles: a novel drug-delivery system. Adv. Mater. 16, 1959-1966. doi: 10.1002/adma.200400771

Bernardos, A., Piacenza, E., Sanceón, F., Hamadi, M., Maleki, A., Turner, R. J., et al. (2019). Mesoporous silica-based materials with bacterial properties. Small 15:1900669. doi: 10.1002/smll.201900669

Borisova, D., Mohwald, H., and Shchukin, D. G. (2011). Mesoporous silica nanoparticles for active corrosion protection. ACS Nano 5, 1939-1946. doi: $10.1021 / \mathrm{nn} 102871 \mathrm{v}$

Böttcher, H., Jagota, C., Trepte, J., Kallies, K. H., and Haufe, H. (1999). Sol-gel composite films with controlled release of biocides. J. Control. Release. 60, 57-65. doi: 10.1016/S0168-3659(99)00053-X

Brunauer, S., Emmett, P. H., and Teller, E. (1938). Adsorption of gases in multimolecular layers. J. Am. Chem. Soc. 60, 309-319. doi: 10.1021/ja0126 $9 \mathrm{a} 023$

Bruschi, M. L. (2015). "Mathematical and physicochemical models of drug release," in Strategies to Modify the Drug Release From Pharmaceutical Systems, ed M. L. Bruschi (Cambridge: Woodhead Publishing), 63-86. doi: 10.1016/B978-0-08-100092-2.00005-9

Cao, N., Zhao, Y., Sang, B., Wang, Z., Cao, L., Sun, L., et al. (2016). Fabrication of autofluorescent porous silica nanoparticles for redox-responsive drug release. Mater. Sci. Eng. C 69, 330-336. doi: 10.1016/j.msec.2016.06.096

Caponetti, E., Pedone, L., Saladino, M. L., Chillura Martino, D. F., and Nasillo, G. (2010). MCM-41-CdS nanoparticles composite material: preparation and characterization. Microporous Mesoporous Mater. 128, 101-107. doi: 10.1016/j.micromeso.2009.08.010

Cavallaro, G., Lazzara, G., and Fakhrullin, R. (2018). Mesoporous inorganic nanoscale particles for drug adsorption and controlled release. Ther. Delivery 9, 287-301. doi: 10.4155/tde-2017-0120

Chan, A. C., Cadena, M. B., Townley, H. E., Fricker, M. D., and Thompson, I. P. (2017). Effective delivery of volatile biocides employing mesoporous silicates for treating biofilms. J. R. Soc. Interface 14:650. doi: 10.1098/rsif.2016.0650

Chauhan, M., Saini, V. K., and Suthar, S. (2020). Ti-pillared montmorillonite clay for adsorptive removal of amoxicillin, imipramine, diclofenacsodium, and paracetamol from water. J. Hazard. Mater. 399:1228322. doi: 10.1016/j.jhazmat.2020.122832

Ciabocco, M., Cancemi, P., Saladino, M. L., Caponetti, E., Alduina, R., and Berrettoni, M. (2018). Synthesis and antibacterial activity of ironhexacyanocobaltate nanoparticles. J. Biol. Inorg. Chem. 23, 385-398. doi: 10.1007/s00775-018-1544-x

Cusimano, M. G., Ardizzone, F., Nasillo, G., Gallo, M., Sfriso, A., Chillura Martino, D., et al. (2020). Biogenic silver nanoparticles inhibit bacterial biofilm formation due to $\mathrm{Ag}+$ release as determined by a novel phycoerythrin-based assay. Appl. Microbiol. Biotechnol. 104, 6325-6336. doi: 10.1007/s00253-020-10686-w

Dai, Z., Liu, Q., Hreniak, D., Dai, J., Wang, W., and Li, J. (2018). Fabrication of $\mathrm{Yb}: \mathrm{Sc}_{2} \mathrm{O}_{3}$ transparent ceramics from co-precipitated nanopowders: the effect of ammonium hydrogen carbonate to metal ions molar ratio. Opt. Mater. 75, 673-679. doi: 10.1016/j.optmat.2017.11.035

David, M. E., Ion, R. -M., Grigorescu, R. M., Iancu, L., and Andrei, E. R. (2020). Nanomaterials used in conservation and restoration of cultural heritage: an up-to-date overview. Materials 13:2064. doi: 10.3390/ma130 92064

Dresler, C., Saladino, M. L., Demirbag, C., Caponetti, E., Chillura Martino, D. F., and Alduina, R. (2017). Development of controlled release systems of biocides for the conservation of cultural heritage. Int. Biodeterior. Biodegrad. 125, 150-156. doi: 10.1016/j.ibiod.2017.09.007

Du, X., Shi, B., Liang, J., Bi, J., Dai, S., and Qiao, S. Z. (2013). Developing functionalized dendrimer-like silica nanoparticles with hierarchical pores as advanced delivery nanocarriers. Adv. Mater. 25, 5981-5985. doi: 10.1002/adma.201302189

Dubey, R. S., Rajesh, Y. B. R. D., and More, M. A. (2015). Synthesis and characterization of $\mathrm{SiO}_{2}$ nanoparticles via sol-gel method for industrial applications. Mater. Today Proc. 2, 3575-3579. doi: 10.1016/j.matpr.2015.07.098

Eyssautier-Chuine, S., Calandra, I., Vaillant-Gaveau, N., Fronteau, G., ThomachotSchneider, C., Hubert, J., et al. (2018). A new preventive coating for building stones mixing a water repellent and an eco-friendly biocide. Prog. Org. Coat. 120, 132-142. doi: 10.1016/j.porgcoat.2018.03.022

Farjadian, F., Roointan, A., Mohammadi-Samani, S., and Hosseini, M. (2019). Mesoporous silica nanoparticles: synthesis, pharmaceutical applications, biodistribution, and biosafety assessment. Chem. Eng. J. 359, 684-705. doi: 10.1016/j.cej.2018.11.156

Fidanza, M. R., and Caneva, G. (2019). Natural biocides for the conservation of stone cultural heritage: a review. J. Cult. Heritage 38, 271-286. doi: 10.1016/j.culher.2019.01.005

Giardina, A., Alduina, R., Gottardi, E., Di Caro, V., Süssmuth, R. D., and Puglia, A. M. (2010). Two heterologously expressed Planobispora rosea proteins cooperatively induce Streptomyces lividans thiostrepton uptake and storage from the extracellular medium. Microb. Cell Fact. 9:44. doi: 10.1186/1475-2859-9-44

Giuliani, G., Messina, E., Stacioli, M. P., Pascucci, M., Riccucci, C., Liotta, L. F., et al. (2020). On-demand release of protective agents triggered by environmental stimuli. Front. Chem. 8:304. doi: 10.3389/fchem.2020.00304

Jiang, X., Tang, X., Tang, L., Zhang, B., and Mao, H. (2019). Synthesis and formation mechanism of amorphous silica particles via solgel process with tetraethylorthosilicate. Ceram. Int. 45, 7673-7680. doi: 10.1016/j.ceramint.2019.01.067

Kraleva, E., Saladino, M. L., Spinella, A., Nasillo, G., and Caponetti, E. (2011). $\mathrm{H}_{3} \mathrm{PW}_{12} \mathrm{O}_{40}$ supported on mesoporous MCM-41 and Al-MCM41 materials: preparation and characterization. J. Mat. Sci. 46, 7114-7120. doi: 10.1007/s10853-011-5505-9

Kruk, M., Antchshuk, V., Jaroniec, M., and Sayari, A. (1999). New approach to evaluate pore size distributions and surface areas for hydrophobic mesoporous solids. J. Phys. Chem. B. 103, 10670-10678. doi: 10.1021/jp992264h

Lavall, R. L., Ferrari, S., Tomasi, C., Marzantowicz, M., Quartarone, E., Fagnoni, M., et al. (2012). MCM-41 silica effect on gel polymer electrolytes based on thermoplastic polyurethane. Electrochim. Acta 60, 359-365. doi: 10.1016/j.electacta.2011.11.073

Lin, Y. S., and Haynes, C. L. (2009). Synthesis and characterization of biocompatible and size-tunable multifunctional porous silica nanoparticles. Chem. Mater. 21, 3979-3986. doi: 10.1021/cm901259n

Liu, Y., Yan, L., Heiden, P., and Laks, P. (2001). Use of nanoparticles for controlled release of biocides in solid wood. J. Appl. Polym. Sci. 79, 458-465. doi: 10.1002/1097-4628(20010118)79:3<458::AID-APP80>3.0.CO;2-H

Lu, J., Liong, M., Zink, J. I., and Tamanoi, F. (2007). Mesoporous silica nanoparticles as delivery system for hydrophobic anticancer drugs. Small 8, 1341-1346. doi: 10.1002/smll.200700005

Lu, J., Shen, H. H., Wu, Z., Wang, B., Zhao, D., and He, L. (2015). Self-assembly of bi-functional peptides on large poremesoporous silica nanoparticles formiRNA binding and delivery. J. Mater. Chem. B 3, 7653-7657. doi: 10.1039/C5TB01133G

Ma, S., Wang, Y., and Zhu, Y. (2011). A simple room temperature synthesis of mesoporous silica nanoparticles for drug storage and pressure pulsed delivery. J. Porous Mater. 18, 233-239. doi: 10.1007/s10934-010-9375-3

Ma, X., Zhao, Y., Ng, K. W., and Zhao, Y. (2013). Integrated hollow mesoporous silica nanoparticles for target drug/siRNA co-delivery. Chem. Eur. J. 19, 15593-15603. doi: 10.1002/chem.201302736

Michaelsen, A., Pinzari, F., Barbabietola, N., and Piñar, G. (2013). Monitoring of the effects of different conservation treatments on paper infecting fungi. Int. Biodeterior. Biodegrad. 84, 333-341. doi: 10.1016/j.ibiod.2012. 08.005

Mourhly, A., Khachani, M., El Hamidi, A., Kacimi, M., Halim, M., and Arsalane, S. (2015). The synthesis and characterization of low-cost mesoporous silica SiO from local pumice rock. Nanomater. Nanotechnol. 5:35. doi: 10.5772/62033

Nandiyanto, A. B. D., Kim, S. G., Iskandar, F., and Okuyama, K. (2009). Synthesis of spherical mesoporous silica nanoparticles with nanometer-size controllable pores and outer diameters. Microporous Mesoporous Mater. 120, 447-453. doi: 10.1016/j.micromeso.2008.12.019

Niculescu, V. C. (2020). Mesoporous silica nanoparticles for bio-applications. Front. Mater. 7:36. doi: 10.3389/fmats.2020.00036

Niu, D., Liu, Z., Li, Y., Luo, X., Zhang, J., Gong, J., et al. (2014). Monodispersed and ordered largepore mesoporous silica nanospheres with tunable pore structure for magnetic functionalization and gene delivery. Adv. Mater. 26, 4947-4953. doi: 10.1002/adma.201400815

Piacenza, E., Presentato, A., Ambrosi, E., Speghini, A., Turner, R. J., Vallini, G. et al. (2018). Physical-chemical properties of biogenic selenium nanostructures 
produced by Stenotrophomonas maltophilia SeITE02 and Ochrobactrum sp. MPV1. Front. Microbiol. 9:3178. doi: 10.3389/fmicb.2018.03178

Piacenza, E., Presentato, A., Zonaro, E., Lemire, J. A., Demeter, M., Vallini, G., et al. (2017). Antimicrobial activity of biogenically produced spherical Senanomaterials embedded in organic material against Pseudomonas aeruginosa and Staphylococcus aureus strains on hydroxyapatite-coated surfaces. Microb. Biotechnol. 10, 804-818. doi: 10.1111/1751-7915.12700

Poma, P., Labbozzetta, M., Zito, P., Alduina, R., Ramarosandratana, A. V., Bruno, M., et al. (2019). Essential oil composition of Alluaudia procera and in vitro biological activity on two drug-resistant models. Molecules 24:2871. doi: 10.3390/molecules 24162871

Popat, A., Liu, J., Hu, Q., Kennedy, M., Peters, B., Lu, G. Q., et al. (2012). Adsorption and release of biocides with mesoporous silica nanoparticles. Nanoscale 4, 970-975. doi: 10.1039/C2NR11691J

Presentato, A., Lampis, S., Vantini, A., Manea, F., Daprà, F., Zuccoli, S., et al. (2020). On the ability of perfluorohexane sulfonate (PFHxS) bioaccumulation by two Pseudomonas sp. strains isolated from PFAS-contaminated environmental matrices. Microorganisms 8:92. doi: 10.3390/microorganisms 8010092

Purpura, G. (1999). Le pitture della grotta di Santa Margherita, and Kalos-Larte in Sicilia. Palermo: Edizioni Kalós.

Qi, K., Cheng, B., Yu, J., and Ho, W. (2017). Review on the improvement of the photocatalytic and antibacterial activities of ZnO. J. Alloys Comp. 727, 792-820. doi: 10.1016/j.jallcom.2017.08.142

Qi, K., Li, Y., Xie, Y., Liu, S. -Y., Zheng, K., Chen, Z., et al. (2019). $\mathrm{Ag}$ loading enhanced photocatalytic activity of g-C3N4 porous nanosheets for decomposition of organic pollutants. Front. Chem. 7:91. doi: $10.3389 /$ fchem.2019.00091

Qi, K., Xing, X., Zada, A., Li, M., and Wang, G. (2020). Transition metal doped $\mathrm{ZnO}$ nanoparticles with enhanced photocatalytic and antibacterial performances: experimental and DFT studies. Ceram. Int. 46, 1494-1502. doi: 10.1016/j.ceramint.2019.09.116

Randazzo, L., Montana, G., Alduina, R., Quatrini, P., Tsantini, E., and Salemi, B. (2015). Flos tectorii degradation of mortars: an example of synergistic action between soluble salts and biodeteriogens. J. Cult. Heritage 16, 838-847. doi: 10.1016/j.culher.2015.04.002

Rubino, S., Pibiri, I., Minacori, C., Alduina, R., Di Stefano, V., Orecchio, S., et al. (2018a). Synthesis, structural characterization, anti-proliferative and antimicrobial activity of binuclear and mononuclear Pt(II) complexes with perfluoroalkyl-heterocyclic ligands. Inorg. Chim. Acta 483, 180-190. doi: 10.1016/j.ica.2018.07.039

Rubino, S., Saladino, M. L., Attanzio, A., Busà, R., Girasolo, M. A., Caponetti, E., et al. (2018b). Loading and release of the complex Pt(II) with the 2,2'-dithiobis(benzothiazole) ligand [Pt(DTBTA)(DMSO)Cl] $\mathrm{CHCl} 3$ into mesoporous silica and studies of antiproliferative activity. Polyhedron 153, 234-239. doi: 10.1016/j.poly.2018.07.006

Ruggiero, L., Crociani, L., Zendri, E., El Habra, N., and Guerriero, P. (2018). Incorporation of the zosteric sodium salt in silica nanocapsules: synthesis and characterization of new fillers for antifouling coatings. Appl. Surf. Sci. 439, 705-711. doi: 10.1016/j.apsusc.2017.12.228

Ruggiero, L., Di Bartolomeo, E., Gasperi, T., Luisetto, I., Talone, A., Zurlo, F., et al. (2019). Silica nanosystems for active antifouling protection: nanocapsules and mesoporous nanoparticles in controlled release applications. J. Alloy Comp. 798, 144-148. doi: 10.1016/j.jallcom.2019.05.215

Russo, M., Armetta, F., Riela, S., Chillura Martino, D., Lo Meo, P., and Noto, R. (2015). Silver nanoparticles stabilized by a polyaminocyclodextrin as catalysts for the reduction of nitroaromatic compounds. J. Mol. Catal. A Chem. 408, 250-261. doi: 10.1016/j.molcata.2015.07.031

Russo, M., Meli, A., Sutera, A., Gallo, G., Chillura Martino, D., Lo Meo, P., et al. (2016). Photosynthesized silver-polyaminocyclodextrin nanocomposites as promising antibacterial agents with improved activity. RSC Adv. 6, 40090-40099. doi: 10.1039/C6RA00042H

Saladino, M. L., Kraleva, E., Todorova, S., Spinella, A., Nasillo, G., and Caponetti, E. (2011). Synthesis, characterization and catalytic activity of mesoporous Mn-MCM-41 materials. J. Alloy Comp. 509, 8798-8803. doi: 10.1016/j.jallcom.2011.06.078
Saladino, M. L., Rubino, S., Colomba, P., Girasolo, M. A., Chillura Martino, D. F., Demirbag, C., et al. (2016). Pt(II) complex @mesoporous silica: preparation, characterization and study of release. Biointerface Res. Appl. Chem. 6, 1621-1626.

Saladino, M. L., Spinella, A., Caponetti, E., and Minoja, A. (2008). Characterization of Nd-MCM41 obtained by impregnation. Microporous Mesoporous Mat. 113, 490-498. doi: 10.1016/j.micromeso.2007.12.007

Sing, K. S. W., Douglas, H., Everett, D. H., Haul, R. A. W., Moscou, L., Pierotti, R. A., et al. (2008). Reporting physisorption data for gas/solid systems. Pure Appl. Chem. 57:16. doi: 10.1002/9783527610044.hetcat0065

Slowing, I. I., Vivero-Escoto, J. L., Wu, C. W., and Lin, V. S. (2008). Mesoporous silica nanoparticles as controlled release drug delivery and gene transfection carriers. Adv. Drug Deliv. Rev. 60, 1278-1288. doi: 10.1016/j.addr.2008. 03.012

Soffritti, I., D’Accolti, M., Lanzoni, L., Volta, A., Bisi, M., Mazzacane, S., et al. (2019). The potential use of microorganisms as restorative agents: an update. Sustainability 11:3853. doi: 10.3390/su11143853

Sorensen, G., Nielsen, A. L., Pedersen, M. M.:, Poulsen, S., Hissen, H., Poulse, M., and Nygaard, S. D. (2010). Controlled release of biocide from silica microparticles in wood paint. Prog. Org. Coat. 68, 299-306. doi: 10.1016/j.porgcoat.2010.03.009

Trapani oggi (2019). Gli affreschi della grotta di Santa Margherita. Available online at: https://www.trapanioggi.it/gli-affreschi-della-grotta-di-santa-margherita (accessed April 25, 2020).

Trewyn, B. G., Nieweg, J. A., Zhao, Y., and Lin, V. S. Y. (2008). Biocompatible mesoporous silica nanoparticles with different morphologies for animal cell membrane penetration. Chem. Eng. J. 137, 23-29. doi: 10.1016/j.cej.2007.09.045

Urzì, C. (2004). Microbial deterioration of rocks and marble monuments of the mediterranean basin: a review. Corros. Rev. 22:441. doi: 10.1515/CORRREV.2004.22.5-6.441

Viana, R. B., da Silva, A. B. F., and Pimentel, A. S. (2012). Infrared spectroscopy of anionic, cationic, and zwitterionic surfactants. Adv. Phys. Chem. 2012:903272. doi: $10.1155 / 2012 / 903272$

Wang, S. (2009). Ordered mesoporous materials for drug delivery. Microporous Mesoporous Mat. 117, 1-9. doi: 10.1016/j.micromeso.2008. 07.002

Warscheid, T. (2003). "The evaluation of biodeterioration processes on cultural objects and approaches for their effective control," in Art, Biology, and Conservation: Biodeterioration of Works of Art, eds R. J. Koestler, V. H. Koestler, A. E. Charola, and F. E. Nieto-Fernandez (New York, NY: The Metropolitan Museum of Art), 14-27.

Warscheid, T., and Braams, J. (2000). Biodeterioration of stone: a review. Int. Biodeterior. Biodegrad. 4, 343-368. doi: 10.1016/S0964-8305(00)00109-8

$\mathrm{Xu}, \mathrm{D}$., Feng, J., and Che, S. (2014). An insight into the role of the surfactant CTAB in the formation of microporous molecular sieves. Dalton Trans. 43, 3612-3617. doi: 10.1039/C3DT53308E

Yaqoob, A. A., Ahmad, H., Parveen, T., Ahmad, A., Oves, M., Ismail, I. M. I., et al. (2020). Recent advances in metal decorated nanomaterials and their various biological applications: a review. Front. Chem. 8:341. doi: $10.3389 /$ fchem. 2020.00341

Zhu, W., Chen, Z., Pan, Y., Dai, R., Wu, Y., Zhuang, Z., et al. (2019). Functionalization of hollow nanomaterials for catalytic applications: nanoreactor construction. Adv. Mater. 31:1800426. doi: 10.1002/adma.201800426

Conflict of Interest: The authors declare that the research was conducted in the absence of any commercial or financial relationships that could be construed as a potential conflict of interest.

Copyright (๑ 2020 Presentato, Armetta, Spinella, Chillura Martino, Alduina and Saladino. This is an open-access article distributed under the terms of the Creative Commons Attribution License (CC BY). The use, distribution or reproduction in other forums is permitted, provided the original author(s) and the copyright owner(s) are credited and that the original publication in this journal is cited, in accordance with accepted academic practice. No use, distribution or reproduction is permitted which does not comply with these terms. 